\title{
PENERAPAN MODEL PEMBELAJARAN KOOPERATIF TIPE JIGSAW BERBASIS KEARIFAN LOKAL UNTUK MENINGKATKAN HASIL BELAJAR BAHASA INDONESIA DI SEKOLAH DASAR
}

\author{
Intan \\ Institut Agama Islam Negeri Palopo \\ Jl. Agatis I, Balandai, Bara, Kota Palopo, Sulawesi Selatan 91914 \\ E-mail: intan.latief@gmail.com
}

\begin{abstract}
This research discusses the low learning outcomes of Indonesian, especially poetry writing material. The purpose of this study was to determine whether there was an increase in student learning outcomes. This research is a classroom action research (CAR) which consists of two cycles, each cycle carried out as many as 3 meetings, with stages of Planning, Action, Observation, and Reflection. The subjects of this study were fifth grade students of SDN 008 Dandang, Sabbang District, North Luwu Regency with 29 students. The results showed that: by applying Jigsaw type cooperative learning based on local wisdom student learning outcomes in Indonesian subjects the material for writing poetry each cycle experienced an increase. Based on the test of student learning outcomes that have been carried out as much as two cycles shows that student learning outcomes have increased, from the first cycle the average value of 52 with a percentage of completeness $80 \%$, while the second cycle the average value of 80 with a percentage of $100 \%$ and has met the KKM that is 70.
\end{abstract}

Keywords: Type Jigsaw Cooperative, Local Wisdom, Student Learning Outcomes

\begin{abstract}
Abstrak
Penelitian ini membahas tentang rendahnya hasil belajar bahasa Indonesia khususnya materi menulis puisi. Tujuan penelitian ini adalah mengetahui apakah ada peningkatan dalam hasil belajar siswa. Penelitian ini adalah penelitian tindakan kelas (PTK) terdiri dari dua siklus, masing-masing siklus dilaksanakan sebanyak 3 kali pertemuan, dengan tahapan Perencanaan, tahap tindakan, tahap Observasi, dan Refleksi. Subjek penelitian ini adalah siswa kelas V SDN 008 Dandang Kecamatan Sabbang Kabupaten Luwu Utara dengan jumlah siswa 29 orang. Hasil penelitian menunjukkan bahwa: dengan diterapkan pembelajaran kooperatif tipe Jigsaw berbasis kearifan lokal hasil belajar siswa pada mata pelajaran bahasa Indonesia materi menulis puisi setiap siklusnya mengalami peningkatan. Berdasarkan tes hasil belajar siswa yang telah dilakukan sebanyak dua siklus menunjukkan hasil belajar siswa mengalami peningkatan, dari siklus I dengan nilai rata-rata 52 dengan persentase ketuntasan 80\%, sedangkan siklus II dengan nilai rata-rata 80 dengan persentase 100\% dan sudah memenuhi nilai KKM yaitu 70.
\end{abstract}

Kata Kunci: Kooperatif Tipe Jigsaw, Kearifan Lokal, Hasil Belajar Siswa..

\section{PENDAHULUAN}

Bahasa Indonesia sebagai suatu bahasa yang berkembang memiliki berbagai ragam, masing-masing berfungsi sebagai alat dalam berkomunikasi baik tulis maupun lisan. Pernyataan tersebut sesuai dengan pernyataan Sukirman Nurjan pada bukunya bahwa bahasa Indonesia merupakan alat mengungkapkan diri baik secara lisan dan tertulis, dari segi rasa, karsa, dan 
cipta, serta pikir, baik secara etis, estetis, dan secara logis (Sukirman Nurdjan, 2014 : 1). Setiap ragam bahasa yang terdapat dalam bahasa Indonesia adalah sejajar. Artinya, setiap ragam dalam Bahasa Indonesia memunyai kedudukan yang sama. Yang berbeda ialah penggunaan kata/istilah dan pada format pengaplikasiannya. Misanya pada ragam tulis ilmiah dan pada ragam tulis fiksi, kedua ragam tersebut memiliki kedudukan yang sama yaitu terdapat kaidah-kaidah penulisan atau bertutur yang harus diikuti. Pada kaidah penulisan yang berhubungan dengan ragam ilmiah seperti makalah, skripsi dan tesis memiliki kaidah tersendiri begitupula dengan kaidah penulisan pada ragam fiksi seperti pada cerpen, puisi, novel dan lainnya. Pernyataan tersebut sesuai dengan pernyataan (Rustan, 2016) bahwa perundangundangan pada dasarnya hanya merupakan salah satu ragam bahasa yang tidak banyak berbeda dengan ragam bahasa Indonesia yang lain. Artinya pada perundang-undangan bahasa yang digunakan harus mengikuti kaidah yang telah ditentukan yaitu penggunaan ragam bahasa yang baku.

Pembelajaran bahasa Indonesia di SD pada hakikatnya adalah pembelajaran keterampilan berbahasa Indonesia yang baik dan benar sesuai dengan tujuan dan fungsinya. Mata pelajaran bahasa Indonesia bertujuan agar siswa memunyai kemampuan berkomunikasi secara efektif serta efisien, sesuai etika yang berlaku, baik secara lisan dan tulisan (Zulela, 2013 : 4). Seperti halnya dalam penulisan beberapa karangan seperti naratif, normatif dan deskriptif harus memiliki tulisan yang rapi serta jelas dengan memerhatikan setiap aspek baik tujuan dan ragam pembaca, penggunaan ejaan dan tanda baca, dan kosa kata yang tepat dengan menggunakan kalimat tunggal dan kalimat majemuk, serta mengapresiasi dan mengepresikaan sastra melalui kegiatan menuliskan hasil sastra berupa cerita dan puisi (ArRiayah, 2018 : 11). Seorang guru dituntut untuk membantu siswa dalam menguasai bahasa Indonesia hal ini mengingat pentingnya bahasa Indonesia bagi kemampuan berbahasa siswa baik tulis maupun lisan.

Terjadinya interaksi antara guru dalam sebagai pengajar dan siswa sebagai pelajar merupakan proses belajar mengajar. Belajar adalah aktivitas pengembangan diri melalui pengalaman, bertumpu pada kemampuan diri belajar di bawah bimbingan pengajar. Mengajar merupakan proses dalam memberikan pengarahan serta memberikan kemudahan dalam menemukan sesuatu berdasarkan potensi yang dimiliki oleh siswa sejak awal (Umar Tirtahardja, 2010 : 52). Kegiatan belajar dan mengajar adalah tema sentral yang menjadi inti pelaksanaan pendidikan, didalamnya terjadi interaksi antara pendidik dan anak didik (Mohammad Muchlis Solichin, 2016 : 138). Ada tiga unsur pembelajaran, yakni tujuan pengajaran (instruksional),

PiJIES: Pedagogik Journal of Islamic Elementary School 
pengalaman (proses) belajar-mengajar, dan hasil belajar. Tujuan instruksional adalah perubahan tingkah laku yang di inginkan dalam diri siswa (Nana Sudjana, 2011 : 2). Guru hakikatnya seorang pendidik yang menjadi tokoh, panutan, dan identifikasi bagi para siswa, dan lingkunganya (E Mulyana, $2013: 37$ ).

Dalam menyampaikan pelajaran khususnya pelajaran bahasa Indonesia telah diperkenalkan berbagai metode pembelajaran, model dan strategi pembelajaran yang dapat di jadikan rujukan dan digunakan dalam proses pembelajaran. Metode pembelajaran merupakan cara yang digunakan oleh tenaga pendidik yang merupakan subjek dari proses pembelajaran untuk menyampaikan bahan pelajaran kepada peserta didik guna mencapai hasil yang telah diinginkan. Memilih metode yang diterapkan dalam proses belajar mengajar harus disesuaikan dengan rumusan tujuan pembelajaran (Syamsu S, 2017 : 23) Strategi pembelajaran yang digunakan oleh guru sebaiknya membuat siswa dapat berpartisipasi dalam pembelajaran yang telah direncanakan sehingga pembelajaran dapat berjalan sesuai dengan tujuan (Thalib, 2018).

Berdasarkan observasi awal peneliti menemukan masalah diantaranya penerapan model pembelajaran yang kurang bervariasi. Guru yang mengajar dengan model pembelajaran yang konvensional sehingga tidak dapat menarik minat siswa dalam mengikuti pelajaran yang disampaikan serta dengan model pembelajaran tersebut kurang mengaktifkan siswa dalam proses pembelajaran dan karena siswa cenderung cepat bosan tentunya akan sangat berpengaruh terhadap hasil belajar yang dicapai oleh siswa (Rustan \& Bahru, 2018). Jika dilihat dari segi hasil, setelah peneliti melakukan tes prasiklus pada kelas V SDN 008 Dandang, hasil tes prasiklus tersebut menunjukkan bahwa masih banyak siswa yang nilainya dibawah KKM. Batas KKM mata pelajaran Bahasa Indonesi di kelas V SDN 008 Dandang adalah 70. Presentase siswa yang tuntas memenuhi KKM hanya 3\% dari 29 siswa dan untuk 97\% siswa lainnya masih dibawah KKM (Kriteria Ketuntasan Minimal) yaitu 70.

Oleh karena itu diperlukan adanya penggunaan model pembelajaran yang bervariasi guna menciptakan iklim pembelajaran yang efektif dan menyenangkan bagi siswa. Untuk itu salah satu model pembelajaran yang dapat diterapkan dalam proses pembelajaran Bahasa Indonesia yaitu dengan menggunakan model pembelajaran. Salah satu model yang dapat digunakan yaitu model pembelajaran kooperatif (cooperative learning), belajar kooperatif menekankan pada kerja kelompok (siswa belajar bersama dan saling membantu). Kerja kelompok membuat 


\section{2 | Intan}

siswa bersemangat untuk belajar aktif untuk saling menampilkan diri atau berperan diantara teman-teman kelompoknya (Hasan Basri, 2014 : 187).

Pembelajaran kooperatif memiliki berbagai macam tipe, salah satunya adalah pembelajaran kooperatif tipe Jigsaw. Jigsaw merupakan salah satu tipe model pembelajaran kooperatif yang dapet diterapkan dimana saja (Made Ena, 2012 : 139). Pembelajaran kooperatif tipe Jigsawini, pada dasarnya membentuk kelompok dimana peran guru diharapkan mampu membantu para siswa agar lebih aktif dalam memberikan pendapat dikelas, agar tidak hanya siswa pintar yang berbicara, namun seluruh siswa harus menyampaikan pendapatnya dengan proporsi yang setara ( Sigit Setyawan, $2013: 33$ ).

Pembelajaran kooperatif tipe Jigsaw dikaitkan dengan kearifan lokal untuk meningkatkan hasil pembelajaran bahasa Indonesia siswa. HG. Quaritch Wales yang menyebut kearifan lokal sebagai "local genius" artinya segala sesuatu yang berkaitan dengan ciri khusus dalam kebudayaan masyarakat atau kelompok tertentu yang dimiliki bersama sebagai suatu akibat pengalamannya dimasa lalu (Irwan Abbas, 2013 : 276). Budaya merupakan identitas diri yang diperlukan dalam pergaulan nasional dan global guna membentuk karakter sehingga tidak terombang ambing dalam arus globaisasi (Rustan, 2001). Salah satu contoh dari warisan budaya berbasis kearifan lokal adalah tudang sipulung. Tudang sipulung salah satu kearifan lokal yang masih melekat kental di desa Dandang, tudang sipulung pada hakikatnya salah satu bentuk komunikasi kelompok dimana berarti berkumpul bersama memusyawarahkan hal-hal yang penting oleh masyarakat setempat (Baharuddin Dollah, 2016 : 177). Tudang sipulung merupakan salah satu cara dalam berkomunikasi antar kelompok yang terdiri dari beberapa kelompok sejenis. Sebagai komunikasi kelompok sangat berpengaruh terhadap proses serta dalam tujuannya pengambilan keputusan, pembentukan sikap dan perilaku manusia dalam menerima suatu hasil keputusan yang telah dirumuskan (Hartomo dan Arnicun Aziz, 2008 : 42). Selain itu, nilai-nilai kearifan lokal juga dapat dijadikan sebagai motivasi bagi siswa agar lebih giat belajar (Darnia, 2019).

Semua yang di terapakan dalam proses pembelajaran tujuannya agar siswa dapat mencapai tujuan belajar yang ingin dicapai. Aktivitas belajar sangat terkait dengan proses pencarian ilmu. Hal tersebut sesuai dengan tujuan dari penelitian ini yaitu untuk meningkatkan aktifitas siswa dalam proses belajar mengajar serta untuk meningkatkan hasil belajar siswa pada pelajaran bahasa Indonesia.

PiJIES: Pedagogik Journal of Islamic Elementary School 


\section{METODE PENELITIAN}

Penelitian ini merupakan penelitian tindakan kelas yang menitik beratkan pada aktivitas pembelajaran di dalam kelas, yang menggunakan pendekatan kualitatif dan kuantitatif.Subjek dalam penelitian ini adalah seluruh siswa dari kelas V Sekolah Dasar Negeri 008 Dandang Kecamatan Sabbang Kabupaten Luwu Utara yang berjumlah 29 siswa yang terdiri dari 15perempuan dan 14 siswa laki-laki. Pengumpulan data dalam penelitian ini menggunakan teknik observasi, teknik dokumentasi dan tes. Data hasil observasi guru selama kegiatan proses pembelajaran berlangsung analisis dan dideskripsikan secara kualitatif guna mencari kekurangan yang terjadi pada setiap pertemuan kemudian diperbaiki pada pertemuan selanjutnya.

Indikator keberhasilan dari penelitian tindakan kelas ini adalah sebagai berikut : Terjadi peningkatan persentase aktivitas belajar siswa yang dilihat selama proses pembelajaran berlangsung melalui peningkatan rata rata persentase setiap aspek yang diamati seperti yang tercantum didalam indikator pada lembar aktivitas siswa. Untuk hasil tes, kriteria keberhasilan yang digunakan adalah mengacu pada peningkatan nilai rata-rata pemahaman siswa pada materi bangun datar antara siklus I dan siklus II. Apabila terjadi peningkatan nilai rata-rata pemahaman siswa baik secara angka maupun kategori, maka penerapan media kertas origami berhasil meningkatkan pemahaman materi bangun datar.

\section{HASIL PENELITIAN}

1. Deskripsi peningkatanaktivitas siswa pada penerapan Model kooperatif tipe Jigsaw berbasis kearifan lokal

Berdasarkan lembar observasi siswa yang menunjukkan bahwa, Siswa aktif mencatat materi pelajaran pada siklus I mencapai rata-rata 20,68\% sedangkan pada siklus II mencapai rata-rata 31,03\% hal tersebut disebabkan adanya motivasi siswa dalam menuliskan gagasannya pada lembar kerja kelompok pada siklus II, Siswa aktif bertanya pada siklus I memperoleh ratarata $20,68 \%$ sedangkan pada siklus II mencapai rata-rata 31,03\% adanya peningkatan tersebut disebabkan adanya rasa ingin tahu siswa terhadap materi yang akan disampaikan, Siswa aktif mengajukan ide pada siklus I memperoleh rata-rata $10,34 \%$ sedangkan pada siklus II mencapai rata-rata $20,68 \%$ terjadinya peningkatan pada siklus II tersebut disebabkan meningkatnya pengetahuan siswa sehingga apabila siswa diminta mengajukan pendapatnya maka siswa tersebut mampu mengemukakan pendapatnya tersebut, siswa yang diam atau tenang $20,68 \%$ sedangkan pada siklus II mencapai rata-rata 31,03\% pada siklus II terjadi peningkatan akibat rasa penasaran siswa ketika guru menyampaikan materi serta menerapkan 
model pembelajaran, siswa terfokus pada materi mencapai 20,68\% sedangkan pada siklus II mencapai $41,37 \%$ hal tersebut disebabkan rasa penasaran siswa terhadap materi yang akan disampaikan, antusias dan kompak pada kelompoknya pada siklus I mencapai rata-rata 20,68\% sedangkan pada siklus II mencapai 41,37\% kekompakan antar kelompok tersebut disebabkan adanya daya saing pada setiap kelompok, kehadiran dan absensi pada siklus I mencapai rata-rata 31,03\% sedangkan pada siklus II mencapai $31,03 \%$ pada kelas $\mathrm{V}$ kehadiran adalah hal yang paling penting, hadir tepat waktu pada siklus I mencapai rata-rata 10,34\% sedangkan pada siklus II mencapai rata-rata $31,03 \%$ siswa yang hadir tepat waktu merupakan siswa yang memiliki tanggung jawab seperti petugas piket, pulang tepat waktu pada siklus I mencapai $31,03 \%$ sedangkan pada siklus II mencapai $31,03 \%$ kedisiplinan tersebut dikarenakan tidak ada siswa yang memiliki catatan kebiasaan membolos pada saat pembelajaran, mengerjakan semua tugas pada siklus I mencapai rata-rata $20,26 \%$ sedangkan pada siklus II mencapai $41,37 \%$ pada siklus II terjadi peningkatan dalam mengerjakan tugas hal tersebut disebabkan rasa tanggung jawab siswa terhadap tugas yang diberikan, ketepatan mengumpulkan tugas sesuai waktunya pada siklus I mencapai rata-rata $20,68 \%$ sedangkan pada siklus II mencapai $41,37 \%$ pada siklus II terjadi peningkatan siswa dalam mengumpulkan tugasnya hal tersebut dikarenakan adanya peringatan kepada siswa yang terlambat mengumpulkan tugasnya, mengerjakan bersama-sama dengan semua anggota kelompok pada siklus I mencapai rata-rata 20,68\% sedangkan pada siklus II mencapai rata-rata $41,37 \%$ terjadi peningkatan pada aspek kekompakan anggota kelompok karena jiwa saing untuk menjadi yang terbaik adalah komponen pendoorongnya. Untuk lebih jelas dapat dilihat pada diagram berikut:

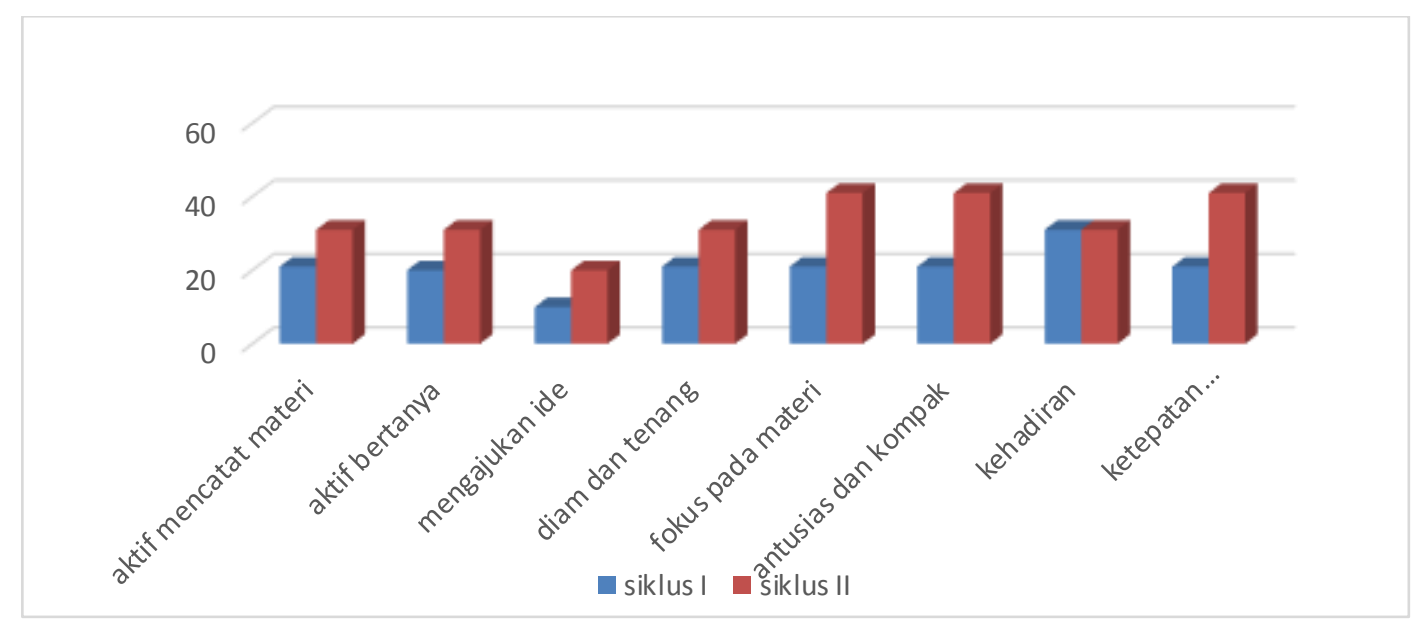

Gambar 1. Diagram 1 Peningkatan Aktifitas Siklus I Dan Siklus Ii

PiJIES: Pedagogik Journal of Islamic Elementary School 
2. Peningkatan hasil belajar siswa pada mata pelajaran bahasa Indonesia dengan menerapkan model kooperatif tipe Jigsaw berbasis kearifan lokal.

Deskripsi nilai rata-rata hasil evaluasi siklus I sehingga nilai rata-rata hasil belajar siswa kelas V SDN 008 Dandang diperoleh dengan rumus ratarata: $\frac{1.525}{29}=52$, jadi nilai rata-rata siswa setelah diterapkan model kooperatif tipe Jigsaw berbasis kearifan lokal dalam pelajaran bahasa Indonesia terse but menunjukkan bahwa dari 29 siswa yang mengikuti tes evaluasi pada siklus I siswa yang mendapat nilai $\geq 70$ sebanyak 4 orang dan yang mendapat nilai dibawah KKM sebanyak 25 orang. Dapat dilihat pada table berikut:

Tabel 1. Hasil tes evaluasi siklus I

\begin{tabular}{|c|c|c|c|c|}
\hline No. & Nilai angka & Kategori & Frekuensi & Persentase \\
\hline 1 & $90-100$ & Sangat baik & - & \\
\hline 2 & $80-89$ & Baik & - & \\
\hline 3 & $70-79$ & Cukup & 4 & $14 \%$ \\
\hline 4 & $0-69$ & Kurang & 25 & $86 \%$ \\
\hline \multicolumn{3}{|c|}{ Jumlah } & 29 & $100 \%$ \\
\hline
\end{tabular}

Berdasarkan tabel tersebut dapat diketahui bahwa dari 29 siswa yang mengikuti tes pada siklus I 0 siswa yang mendapat nilai kategori sangat baik, 4 atau 14\% siswa yang mendapat nilai yang mendapat nilai kategori baik, 9 atau 31\% siswa yang mendapat nilai kategori cukup, 4 atau 14\% siswa mendapat kategori kurang dan 12 atau 41\% siswa yang mendapat kategori gagal. Berdasarkan deskripsi tersebut peneliti melanjutkan penelitiannya pada tahap II

Tabel 2. Hasil tes evaluasi siklus II

\begin{tabular}{|c|c|c|c|c|}
\hline No. & Nilai angka & Kategori & Frekuensi & Persentase \\
\hline 1 & $90-100$ & Sangat baik & - & $\%$ \\
\hline 2 & $80-89$ & Baik & 16 & $55 \%$ \\
\hline 3 & $70-79$ & Cukup & 13 & $45 \%$ \\
\hline 4 & $0-69$ & Kurang & 0 & $\%$ \\
\hline \multicolumn{2}{|c|}{ Jumlah } & $\mathbf{2 9}$ & $\mathbf{1 0 0 \%}$ \\
\hline
\end{tabular}

Berdasarkan tabel tersebut dapat diketahui bahwa dari 29 siswa yang mengikuti tes pada siklus II terdapat 16 atau 55\% siswa yang mendapat nilai 
kategori sangat baik, 13 atau 45\% siswa yang mendapat nilai kategori baik, tidak ada siswa yang mendapat kategori cukup dan tidak ada siswa yang mendapat kategori gagal. Berdasarkan indicator keberhasilan siswa, jika siswa mendapat nilai rata-rata klasikal $75 \%$ maka tujuan penelitian sudah tercapai.

Hasil evaluasi siklus II nilai rata-rata hasil belajar siswa kelas V SDN 008 Dandang diperoleh dengan rumus rata-rata $\frac{2.325}{29}=8,017$ jadi nilai ratarata siswa dengan menggunakan model Jigsaw berbasis kearifan lokal dalam pembelajaran bahasa Indonesia pokok tersebut menunjukkan bahwa dari 29 siswa yang mengikuti tes evaluasi pada siklus II siswa yang mendapat nilai $\geq$ 70 sebanyak 29 orang dan tidak ada yang mendapat di bawah nilai KKM.

Hasil analisis menunjukkan bahwa adanya perbedaan besar antara hasil Siklus I dan Siklus II, Jumlah siswa yangtelah menerimatingkat "sangat baik" dalam siklus I ialah 0 siswa dan dalam siklus II 16 siswa. Pada siswa yang menerima tingkat "baik" dalam dalam siklus I ialah 4 siswa dan dalam siklus II 13 siswa, yang menerima tingkat "cukup" dan dalam siklus I ialah 9 siswa dan dalam siklus II 0 siswa, pada tingkat "kurang" dalam, siklus I 4 siswa dan dalam siklus II 0 siswa sedangkan tingkat "gagal" 12 siswa dan dalam siklus II 0 siswa.

\section{PEMBAHASAN PENELITIAN}

Berdasarkan pengamatan siklus I dan siklus II menunjukkan adanya perubahan dalam hasil pembelajaran bahasa Indonesia meskipun tidak sepenuhnya meningkat, tetapi ada sedikit perubahan. Hal tersebut sesuai dengan pernyataan Soekanto dalam Meyta bahwa model berfungsi sebagai pedoman para perancang pembelajaran dan para pengajar dalam merancanakan aktivitas belajar mengajar (Meyta, 48 : 2017). Dengan pernyataan tersebut dapat diartikan bahwa dengan adanya model maka guru/pengajar lebih mudah dalam memberikan pengajaran kepada siswa.Sebelum diterapkan model pembelajaran Jigsawsiswa sulit menemukan ide dan berimajinasi dalam menulis puisi tapi setelah diterapkannya model kooperatif tipe Jigsaw berbasis kearifan lokal siswa lebih bersemangat dikarenakan siswa dan teman kelompok saling membantu untuk memperoleh nilai yang baik. Peryataan tersebut sesuai dengan pernyataan Juwahir bahwa tujuan dari model Jigsaw ialah mengembangkan kerja tim, keterampilan belajar kooperatif dan penguasaan materi. Selain hasil pengamatan siklus I yang mengalami peningkatan siklus II juga mengalami peningkatan yang sangat baik. Seperti keantusiasan siswa dalam 
membuat karangan puisi lebih menjadi terarah dan mereka saling kompak untuk membuat yang terbaik.

Peningkatan aktivitas belajar siswa dalam menulis puisi ditunjukkan dari pemerolehan observasi siswa selama pembelajaran berlangsung mulai dari pembukaan pembelajaran hingga pada akhir pertemuan pada setiap siklus, diketahui sebagian siswa aktivitas belajarnya meningkat setelah diterapkannya model kooperatif tipe Jigsaw berbasis kearifan lokal apabila dibandingkan dengan aktivitas sebelum diterapkan model tersebut. Dalam penerapan model kooperatif tipe Jigsaw lebih difokus aktivitas siswa terhadap kelompoknya, adapun pada pembelajaran ini siswa terlihat aktif dalam membantu pemimpin kelompok untuk menyelesaikan tugas, sesuai dengan pendapat Rusman dalam Yusnimar bahwa pembelajaran kooperatif Jigsaw menunjukkan interaksi kooperatif yang memiliki pengaruh positif terhadap perkembangan anak berupa meningkatkan hasil belajar dan meningkatkan perilaku penyesuaian sosial positif (Yusnimar, 2014: 5)

Meningkatnya aktivitas siswa dalam pembelajaran bahasa Indonesia didukung juga dengan kegiatan belajar mengajar yang baik. Peningkatan secara proses dapat dilihat dengan adanya peningkatan kualitas pembelajaran dari awal siklus I hingga siklus II, yaitu siswa lebih aktif dalam mengikuti pembelajaran. Adanya peningkatan perilaku siswa yang tadinya pasif menjadi lebih aktif, berbudaya dan bersemangat dalam proses pembelajaran khususnya dalam pembelajaran bahasa Indonesia menulis puisi setelah diterapkannya model kooperatif tipe Jigsaw berbasi kearifan lokal, sehingga tugas yang diberikan kepada siswa dapat disesaikan dengan baik dan tepat waktu.

Keaktifan siswa aktif dalam pembelajaran memiliki indikator yaitu dimana siswa aktif dalam mengerjakan tugas kelompok. Siswa juga berani menyampaikan pendapat setelah melakukan tudang sipulung. Berdasarkan hasil pengamatan yaitu penerapan model kooperatif tipe Jigsaw berbasi keaifan lokal dapat dikatakan pada kategori baik. Dapat dilihat pada saat proses pembelajaran berlangsung siswa terlihat aktif dalam mengikuti pembelajaran seperti pada saat pemimpin kelompok bertukar pikiran dengan pemimpin kelompok lainnya. Berdasarkan hasil yang diperoleh, diketahui bahwa trjadi peningkatan hasil belajar bahasa Indonesia pada siswa kelas V SD 008 Dandang pada proses pembelajaran berlangsung, hal ini terbukti dari meningkatnya aktivitas belajar yang terdapat pada siswa setelah diterapkannya model kooperatif tipe Jigsaw berbasis kearifan lokal. Hal ini ditunjukkan dari adanya peningkatan aktivitas belajar yang diperoleh dari hasil lembar observasi. observasi pada siklus I tercatat sikap yang terjadi pada setiap siswa terhadap pembelajaran bahasa Indonesia. Sikap siswa 
tersebut diperoleh dari lembar observasi pada setiap pertemuan yang dicatat pada setiap siklus, lembar observasi tersebut digunakan untuk mengetahui perubahan cara mengajar guru dan sikap siswa selama proses belajar mengajar berlangsung di kelas pada setiap pertemuan.

Dalam pembahasan ini diuraikan hasil penelitian mengenai peningkatan hasil belajar bahasa Indonesia melalui penerapan model pembelajaran kooperatif tipe Jigsaw berbasis kearifan lokal. Berdasarkan penelitian, penggunaan model Jigsaw berbasis kearifan lokal ternyata dapat meningkatkan hasil belajar bahasa Indonesia pada siswa kelas V SDN 008 Dandang kecamatan Sabbang. Hal ini dikarenakan pembelajaran menggunakan model Jigsaw berbasis kearifan lokal dalam proses pembelajaran mampu menarik perhatian siswa sehingga membantu dalam upaya peningkatan pemahaman siswa terhadap materi yang telah disampaikan guru. Dalam menerapkan model pembelajaran kooperatif tipe Jigsaw berbasis kearifan lokal, guru dapat menerapakan berbagai jenis teknik, permainan yang mengutamakan kerjasama kelompok yang menarik dalam penyampaian materi sehingga mampu menghilangkan kejenuhan siswa dalam belajar.

Menurut Syamsu, model pembelajaran merupakan pola kegiatan secara terstruktur membimbing dan mengarahkan jalannya proses pembelajaran, terciptanya pembelajaran yang menarik dalam kerangka membelajarkan siswa menuju pencapaian tujuan pembelajaran yang telah ditetapkan. Penggunaan model pembelajaran yang tepat pada dasarnya bertujuan untuk menciptakan kondisi pembelajaran yang memungkinkan siswa dapat belajar secara aktif dan menyenangkan sehingga siswa dapat meraih hasil belajar dan prestasi yang optimal.

Hasil belajar siswa digunakan untuk mengetahui sejauh mana pemahaman siswa terhadap materi pembelajaran yang dinyatakan dalam bentuk nilai. Menurut Nawawi menyatakan bahwa prestasi belajar dapat diartikan sebagai tolak ukur untuk mengetahui keberhasilan siswa dalam memahami pembelajaran berupa materi pelajaran di sekolah yang dinyatakan dalam skor penilaian yang diperoleh dari adanya tes pada sejumlah materi yang ditentukan. Hasil belajar adalah perubahan perilaku yang relatif menetap dalam diri seseorang sebagai akibat dari interaksi seseorang dengan lingkungannya. Hasil belajar memiliki beberapa aspek atau kategori yang pada dasarnya merujuk kepada aspek kognitif, afektif, dan psikomotorik. Berdasarkan presentase ketuntasan hasil belajar siswa kelas $\mathrm{V}$ SDN 008 Dandang setelah menerapkan model pembelajaran kooperatif tipe Jigsaw berbasis kearifan lokalpada pembelajaran bahasa Indonesia, dapat

PiJIES: Pedagogik Journal of Islamic Elementary School 
dilihat bahwa banyaknya siswa yang tuntas pada siklus I sebanyak 4 siswa atau 14\% dan banyaknya siswa yang tidak tuntas sebanyak 25 siswa atau $86 \%$, sedangkan siswa yang tuntas pada siklus II sebanyak 29 siswa sekitar $100 \%$.

\section{PENUTUP}

Hasil analisis data penelitian, serta rumusan masalah maka dapat diambil kesimpulan bahwa : (1) Penerapan model pembelajaran kooperatif tipe Jigsaw berbasis kearifan lokal pada mata pelajaran di bahasa Indonesia diterapkan disetiap siklus. Penerapan model Jigsaw di kelas V SDN 008 Dandang terbilang mudah untuk diterapkan karena adanya kerjasama dari siswa, dan guru. Dimana setelah kegiatan awal, sebelum pemberian materi pembelajaran siswa duduk melantai bersama dengan anggota kelompok masing-masing, lalu mengerjakan tugas yang diberikan oleh guru bersamasama. (2) Penerapan model pembelajaran kooperatif tipe Jigsaw berbasis kearifan lokal pada mata pelajaran di bahasa Indonesia terbilang berhasil. Dilihat dari adanya peningkatan hasil belajar siswa disetiap siklus, hal ini dapat terlihat dari perolehan skor rata-rata hasil belajar siswa pada siklus I yaitu 52\% sedangkan perolehan skor hasil belajar siswa pada siklus II yaitu 80\% dapat dikategorikan hasil belajar siswa meningkat.

\section{DAFTAR PUSTAKA}

Abbas, Irwan. 2013."Pappaseng: Kearifan Lokal Manusia bugis yang Terlupakan". Sosio humaniora.

Ar-Riayah.2018.Jurnal Pendidikan Dasar. Vol.2, No.1

Darnia. (2019). Efektivitas Pemberian Penguatan Berkearifan Lokal Terhadap Motivasi Belajar Ilmu Pengetahuan Sosial (IPS) Siswa Di

Kelas III SD Islam Datok Sulaiman Bagian Putri Palopo. Pedagogik Journal of Islamic Elementary School, 2(1), 41-54.

Juwahir,2018. Jurnal Taman vokasi. Vol.6. No.1

Kementerian Agama RI, Al-Qur'an TerjemahdanTajwid, Bandung: Sygma, 2014

La Sulo, Umar,Tirtarahardja, ,Pengantar Pendidikan, Makassar, 2010.

Made Wena, 2012. Strategi Pembelajaran Inovatif Kontemporer, Jakarta, Bumi Aksara.

Meyta Printandi, 2017. Jurnal pendidikan ekonomi UM metro. Vol. 5, No.1

MulyasaE, Menjadi Guru Profesional, Cet. I: Bandung, RemajaRosdakarya, 2013.

Muslich Masnur 2012. Melaksanakan PTK itu Mudah, Cet VI; Jakarta: Bumi Aksara. 
Nurdjan, Sukirman,2014.Dasar - dasar Memahami Bahasa Indonesia, Cet II; Palopo Sulawesi Selatan: Read Institute Press.

Rustan, E. (2001). Budaya Leluhur dalam Memperkukuh Tatanan Masyarakat di Era Globalisasi. Seminar Internasional Pemertahanan Identitas Masyarakat Multikultural Di Era Globalisasi, 79-86. Surabaya.

Rustan, E. (2016). Analisis Penggunaan Bahasa Indonesia Laras Hukum Pada Putusan Perkara Ekonomi Syariah Pengadilan Agama Makassar. AlAmwal: Journal of Islamic Economic Law, 1(2), 166-176. https://doi.org/10.24256/alw.v1i2.278

Rustan, E., \& Bahru, M. S. (2018). Penguatan Self Confidence dalam Pembelajaran Matematika melalui Metode Suggestopedia. AlKhwarizmi: Jurnal Pendidikan Matematika Dan Ilmu Pengetahuan Alam, 6(1), 1-14.

Rocmah, Luluk Iffatur. 2015. RifkiA fandi, Pramuka Sebagai Wadah Mengembangkan Life Skill Mahasiswa Calon guru Pada Perguruan Tinggi LPTK, Jurnal Pedagogia, Vol.4, No.2, Sidoarjo, Edisi Agustus.

Sanusi Syamsu, 2017. Strategi Pembelajaran, Makassar, Nas Media Pustaka. Sanusi, Syamsu. 2015.Strategi Pembelajaran Meningkatkan Kompetensi Guru, Makassar: AksaraTimur.

Setyawan, Sigit. 2013.Nyalakan Kelasmu (20Metode Mengajar Dan Aplikasinya),Cet.1 ,Jakarta, PT.Grasindo.

Sudjana, Nana. 2011.Penilaian Hasil Proses Belajar Mengajar, Bandung, Remaja Rosdakarya.

Sukardjo M, Ukim Komarudin. 2013. Landasan Pendidikan Konsep dan Aplikasinya, Jakarta, Rajawali Pers.

Suprijono, Agus. 2009.Cooperatif learning Teori dan Aplikasi PAIKEM, Yogyakarta: Pustaka belajar.

Thalib, A. (2018). Pendekatan Keterampilan Proses Dalam Meningkatkan Hasil Belajar Bahasa Indonesia. Pedagogik Journal of Islamic Elementary School, 1(1), 23-36.

Wahyuni, Nur,Esa.2012. Baharuddin, Teori Belajar dan Pembelajaran, Jogjakarta: Ar-Ruzz Media.

Yusnimar, 2014. Jurnal UNP Vol.1 No.2

Zulela, 2013. Pembelajaran Bahasa Indonesia Apresiasi Sastra di Sekolah Dasar, Bandung, Remaja Rosdakarya Offset. 